\title{
MINERAL RESOURCE POTENTIAL OF THE WILDERNESS AND ROADLESS AREAS OF THE WHITE MOUNTAIN NATIONAL FOREST, COOS, GRAFTON, AND CARROLL COUNTIES, NEW HAMPSHIRE
}

\author{
By \\ Robert H. Moench and Frank C. Canney, U.S. Geological Survey \\ and \\ Gertrude C. Gazdik, U.S. Bureau of Mines
}

STUDIES RELATED TO WILDERNESS

Under the provisions of the Wilderness Act (Public Law 88-577, September 3, 1964) and related acts, the U.S. Geological Survey and the U.S. Bureau of Mines have been conducting mineral surveys of wilderness and primitive areas. Areas officially designated as "wilderness," "wild," or "canoe" when the act was passed were incorporated into the National Wilderness Preservation System, and some of them are presently being studied. The act provided that areas under consideration for wilderness designation should be studied for suitability for incorporation into the Wilderness System. The mineral surveys constitute one aspect of the suitability studies. The act directs that the results of such surveys are to be made available to the public and be submitted to the President and the Congress. This report discusses the results of a mineral survey of the Great Gulf and Presidential-Dry River Wilderness Areas, and the Dartmouth Range, Wild River, Pemigewasset, Kinsman Mountain, Mount Wolf-Gordon Pond, Jobildunk, Carr Mountain, Sandwich Range, and Dry River Extension (two parcels) Roadless Areas, all in the White Mountain National Forest, Coos, Grafton, and Carroll Counties, New Hampshire. The Great Gulf Wilderness was established when the Wilderness Act was passed in 1964, and the Presidential-Dry River Wilderness was established by Public Law 93-622, January 3, 1975. Generally referred to as roadless areas, the Dartmouth Range, Wild River, Pemigewasset, Kinsman Mountain, Mount Wolf-Gordon Pond, Carr Mountain, and Jobildunk areas were classified as Further Planning Areas, and the Dry River Extension and Sandwich Range as Proposed Wildernesses during the Second Roadless Area Review and Evaluation (RARE II) by the U.S. Forest Service, January 1979.

\section{MINERAL RESOURCE POTENTIAL SUMMARY STATEMENT}

The mineral resource potential of 12 wilderness and roadless areas of the White Mountain National Forest in north-central New Hampshire was investigated in 1980-82. The total area of the 12 separate parcels is about 330 $\mathrm{mi}^{2}$ (square miles); the parcels were combined into one study area of about $1,300 \mathrm{mi}^{2}$.

A moderate mineral resource potential is assigned to about $400 \mathrm{mi}^{2}$ of the study area, centering on but not restricted, to the Jurassic White Mountain batholith, for tin deposits of several kinds, and associated deposits containing lead, zinc, uranium, niobium, beryllium, and thorium. The area of moderate resource potential covers approximately the eastern two-thirds of the Pemigewasset Roadless Area, all of the Sandwich Range Roadless Area, the southern parcel of the Dry River Extension Roadless Area, and approximately the southern half of the Presidential Range-Dry River Wilderness Area. This classification is based mainly on geochemical data; it is supported by a study of abandoned small mines and prospects, and by the geologic and mineral associations of the Conway Granite, a tin-specialized biotite granite that is the most likely source of the tin and other elements of high abundance in stream sediments. However, only sparse evidence of mineralization is known in bedrock.

A low mineral resource potential for tungsten, molybdenum, and copper in stratabound deposits, and for tin in veins is assigned to about $35 \mathrm{mi}^{2}$ in the Jobildunk Roadless Area and small parts of the Mount Wolf-Gordon Pond and Kinsman Mountain Roadless Areas. This classification is based mainly on geochemical data; it is supported by the presence of a geologic terrane that is favorable for occurrence of stratabound deposits containing tungsten (and molybdenum), stratabound copper deposits, and local tin-bearing veins. This small area is not promising for the occurrence of important mineral deposits, because the favorable geologic terranes within it are smaller still.

Large parts of the study area have metamorphosed Silurian and Lower Devonian sedimentary rocks that have weakly anomalous amounts of copper, but the mineral resource potential is unknown. The study area also contains nonmetallic commodities, such as sand and gravel, dimension stone, refractory minerals, industrial pegmatite minerals, gems, peat, and diatomaceous earth, but these commodities can be obtained in more accessible areas elsewhere. 


\section{INTRODUCTION}

The White Mountain National Forest contains 2 established wilderness areas and 10 additional RARE II roadless areas, covering a total of about $330 \mathrm{mi}^{2}$ (fig. 1). In order to treat all the 12 separate areas as a single geologic entity, they were combined into one study area of about $1,300 \mathrm{mi}^{2}$, which includes adjacent nonwilderness areas.

The study area is mountainous and includes several of the highest peaks in the northeastern United States. The highest peak, Mount Washington, has an elevation of $6,288 \mathrm{ft}$ and rises some $1,500 \mathrm{ft}$ above treeline. A network of excellent hiking trails is maintained by the U.S. Forest Service, the Appalachian Mountain Club, and other hiking clubs, and provides access to most parts of the roadless and wilderness areas. The area is a major watershed and it serves important recreational needs for the populous eastern corridor.

This report is based on joint investigations by the U.S. Bureau of Mines (USBM) and the U.S. Geological Survey (USGS) and integrates previous studies as they relate to mineral resources. The USBM studies were conducted in the fall of 1980 and in the spring of 1981. Descriptions and data on mines and prospects in the area are summarized by Gazdik and others (in press); information on sand and gravel, dimension stone, silica, refractory minerals, industrial pegmatite minerals, gems, peat, and diatomaceous earth is also included. The USGS investigations were conducted in the summers of 1980-82, and were integrated with an ongoing multidisciplinary study of mineral resources of the Shearbrooke and Lewiston $1^{\circ} \times 2^{\circ}$ quadrangles under the Conterminous United States Mineral Assessment Program (CUSMAP). The detailed results of the geologic mapping are presented in a report by Hatch and Moench (in press). The geochemical survey, which included sampling and analyses of stream sediments, of heavy-mineral concentrates from these sediments, and of selected rock samples, are reported by Canney and others (in press). A geophysical survey that involved both gravity and magnetic traverses in the study area is described and portrayed on a set of maps by Bothner (in press).

\section{GEOLOGIC SETTING OF MINERAL RESOURCES}

The most conspicuous feature of the bedrock geology of the study area is the White Mountain batholith, the largest and most complex body within a northwest-trending belt of isolated Mesozoic plutons and overlapping stocks, ring dikes, and cauldrons containing related volcanic rocks (see index on fig. 1). The mineral resource potential of the area is associated with these rocks, which constitute the White Mountain Plutonic-Volcanic Suite, the name that is currently used (Billings, 1956). Rocks of the entire suite range in age from Triassic to Cretaceous, as shown by isotopic dating; however, in the study area (fig. 2) all isotopic dates except those for the small Cretaceous intrusions at Hart Ledge and Mount Tripyramid indicate a Jurassic age (Eby and Creasy, 1983; Hatch and Moench, in press). The White Mountain stocks, ring dikes, and cauldrons sharply truncate the structural grain of an early and middle Paleozoic terrane of plutonic rocks and high-rank metamorphic rocks. Only the White Mountain Suite and metavolcanic rocks of Devonian and Ordovician age, which have important mineral resource potential, are shown in figure 2 .

Resources of the Paleozoic metamorphic-plutonic terrane

The central part of the metamorphic terrane is characterized by a great thickness of complexly folded sillimanite-zone schist, gneiss, and migmatite, which is divided by Hatch and Moench (in press) into several named formations of Silurian to Early Devonian age. Some of the rocks are sufficiently aluminous to contain abundant refractory sillimanite, as at the Moses prospect about $1 \mathrm{mi}$ southwest of the Carr Mountain Roadless Area. Other concentrations of sillimanite were identified in the Carr Mountain and Great Gulf areas. These would require extensive beneficiation; furthermore large resources of much higher quality material exist in the southeastern United States.

The geochemical data (Canney and others, in press) indicate that the Silurian and Devonian metasedimentary rocks in large parts of the Wild River and Jobildunk areas have slightly high values of copper. Analyses of stream sediments also define a broad area of weakly anomalous copper values in the northeastern part of the study area, and the northwestern lobe of this anomaly approximately coincides with a belt of moderately high copper in nonmagnetic heavy mineral concentrates from stream sediments. This weak copper anomaly covers perhaps 90 percent of the metasedimentary rocks exposed northeast of the White Mountain batholith; most areas underlain by plutonic rocks are outside the anomaly. A much smaller copper anomaly near the western side of the area approximately coincides with the metagraywacke of the Littleton Formation in the Mount Moosilauke septum (Hatch and Moench, in press). This anomaly, also defined by sediment samples, overlaps area B shown in figure 2. Although the data do not suggest the presence of minable copper deposits, they indicate that the metasedimentary rocks may be widely metalliferous and deserve regional study for possible sediment-hosted stratabound mineral deposits. The inferred sedimentary setting of the Silurian and Devonian formation, in a marine basin flanked by volcanic tracts, is favorable for the origin of such deposits.

Two units of metamorphosed volcanic rocks are distinguished separately on figure 2 , because of their possible mineral resource significance. Metavolcanic rocks of the Littleton Formation, exposed in a narrow belt near the northwestern margin of the study area, contain basaltic amphibolite, dark laminated volcaniclastic metagraywacke, and minor amounts of white metafelsite. These rocks are associated with a larger tract of metagraywacke mapped by Hatch and Moench (in press). The belt of metavolcanic rocks contains the small abandoned Coppermine Brook mine, which produced copper from a thin stratiform lens of chalcopyrite, quartz, and probably secondary bornite and native copper. Because this deposit conforms to the contact between metabasalt and metafelsite, a syngenetic volcanic origin is inferred. This interpretation is supported by geochemical data. Whereas analyses of heavy-mineral concentrates obtained upstream from the Coppermine Brook mine 
did not yield anomalous abundances of metals, a concentrate obtained downstream from the mine yielded 3,000 ppm copper and 2,000 ppm tungsten. The Littleton metavolcanics deserve further study for the possible occurrence of stratabound deposits of these metals and, as suggested by the geochemical data, also molybdenum.

The Ammonoosuc Volcanics, exposed only at the western and northwestern edges of the study area, are part of a single belt that contains the Ore Hill zinclead mine and the Franconia iron mine. This belt is part of an extensive tract in New England of complexly interstratified mafic to felsic marine volcanic rocks that host several known massive-sulfide deposits (Gair and Slack, 1979). The Ore Hill mine yielded about 100,000 tons of ore of unknown grade; underground channel sampling by the U.S. Bureau of Mines showed 0.5 percent copper, 21 percent zinc, 11 percent lead, $2.7 \mathrm{ppm}$ gold, and $274 \mathrm{ppm}$ silver (Gair and Slack, 1979). The mine was developed in a recognized stratabound volcanogenic massive-sulfide deposit (Secord and Brown, 1983). Annis (1982) has investigated the Franconia iron mine in detail. He has shown that it developed an extensive layer of volcanichosted exhalative iron-formation. Because massivesulfide deposits tend to occur in clusters in volcanic tracts, some having abundant iron-formation, the Ammonoosuc belt at the west edge of the study area could have a high potential for the occurrence of other volcanogenic massive-sulfide deposits.

The areas underlain by Ammonoosuc Volcanics also approximately coincide with a broad tungsten anomaly, and contain local molybdenum and copper, defined by heavy mineral concentrates (Canney and others, in press). Accordingly, the Ammonoosuc (as well as the metavolcanics of the Littleton Formation) deserves further study for stratabound tungsten deposits, in addition to massive-sulfide deposits containing base and precious metals.

Paleozoic plutonic rocks of the study area include various granitic rocks of the Ordovician Oliverian Plutonic Suite, Silurian Moody Ledge Granite, various named and unnamed foliated granitic rocks of Devonian age, and largely unfoliated lightgray two-mica granite of Devonian age. Isotopic dating has shown that the Oliverian plutons were emplaced about $440-450 \mathrm{~m} . \mathrm{y}$. ago, in Late Ordovician time. A large body of granite of the same age in northwestern Maine contains a large, as yet subeconomic copper-molybdenum porphyry deposit (Catheart prospect, in the Attean Quartz Monzonite), but no evidence for the occurrence of comparable deposits is recognized in or near the study area. Pegmatite dikes are associated with all these rocks. Page (1980) noted that uranium-bearing pegmatite dikes tend to be associated with the granodioritic Bethlehem Gneiss, one of the principal members of the Devonian suite of plutons in western New Hampshire. These pegmatites are small and low grade. The margins of two important pegmatite districts extend into the study area: the Rumford-Paris district, which lies mainly to the east in Maine, and the Grafton district of west-central New Hampshire, the northern tip of which is in the southwest corner of the study area. Pegmatites of both districts have yielded substantial amounts of industrial mica and feldspar and byproduct beryl, and both districts contain famous mineral collecting localities. With the exception of mica in the Carr Mountain area, pegmatite dikes constitute a negligible resource in the study area.

Two-mica granite similar to that of the study area is recognized worldwide for its high tin, tungsten, beryllium, lithium, and uranium contents (Boudette, 1977 , p. 24). Although similar rocks further southeast in New England have yielded Mississippian to Devonian isotopic ages of about 323 to more than 370 m.y., for simplicity the two-mica granites of the study area are assimed to be entirely Devonian in age. In the study area, unfoliated two-mica granite forms discrete plutons and countless small dikes intrusive into all the other Paleozoic rocks. It constitutes about 20 percent of the Paleozoic plutonic rocks of the area, or about 5 percent of the bedrock of the Paleozoic terrane.

Near New London, N.H., about $30 \mathrm{mi}$ southwest of the study area, two-mica granite hosts an occurrence of secondary uranium minerals (renardite, and possibly metaautunite and torbernite), principally along subvertical joints that strike east-west (Bothner, 1978). Bothner noted that the known deposits there are alined subparallel to possible northwest-trending lineaments described by Page $(1980$, p. 18) in westcentral New Hampshire. Fracture-controlled deposition of the uranium is indicated, probably by precipitation from circulating ground water. The twomica granite of that area contains averages of about $15 \mathrm{ppm}$ uranium and $10 \mathrm{ppm}$ thorium, and is the likely source of uranium in the secondary deposits.

Although we have no data on the amount of uranium in the two-mica granite of the study area, its uranium content may be comparable to that of the New London area, for such granite throughout New England is known to be uraniferous. As shown in table 1, however, two-mica granite from the study area is distinctly less specialized than the Conway Granite in minor-oxide and minor-element composition, according to the criteria of Tischendorf (1977). These data and the geochemical data of Canney and others (in press) suggest that the two-mica granites of the study area are less favorable hosts for secondary uranium deposits than the Conway Granite.

Analyses of uranium in samples of stream sediments define a small uranium anomaly at the southeast side of the Dartmouth Range Roadless Area, where it overlaps a body of two-mica granite. This anomaly is insignificant, however, when compared to the uranium anomaly that occurs within the principal tin anomaly of the White Mountain batholith (fig. 2, area A), and the possibility that important secondary uranium deposits occur in the Dartmouth Range area is correspondingly smaller. The uranium anomaly in area $A$ is probably specifically related to the Conway Granite. Although typical Conway may contain no more uranium than typical two-mica granite, the total radioactivity of the Conway is greater because of a much greater thorium content. Accordingly, the possible occurrence of uranium in veins or along joints in the Conway may be functions of relatively high uranium contents of the Conway combined with a favorable environment for a radioactively-generated hydrothermal system (Fehn and others, 1978).

\section{Resources of the Mesozoic White Mountain} intrusive-volcanic suite

Some 35 years ago, Read (1948, p. 8) observed: "so noteworthy is the identity of the Nigerian and New 


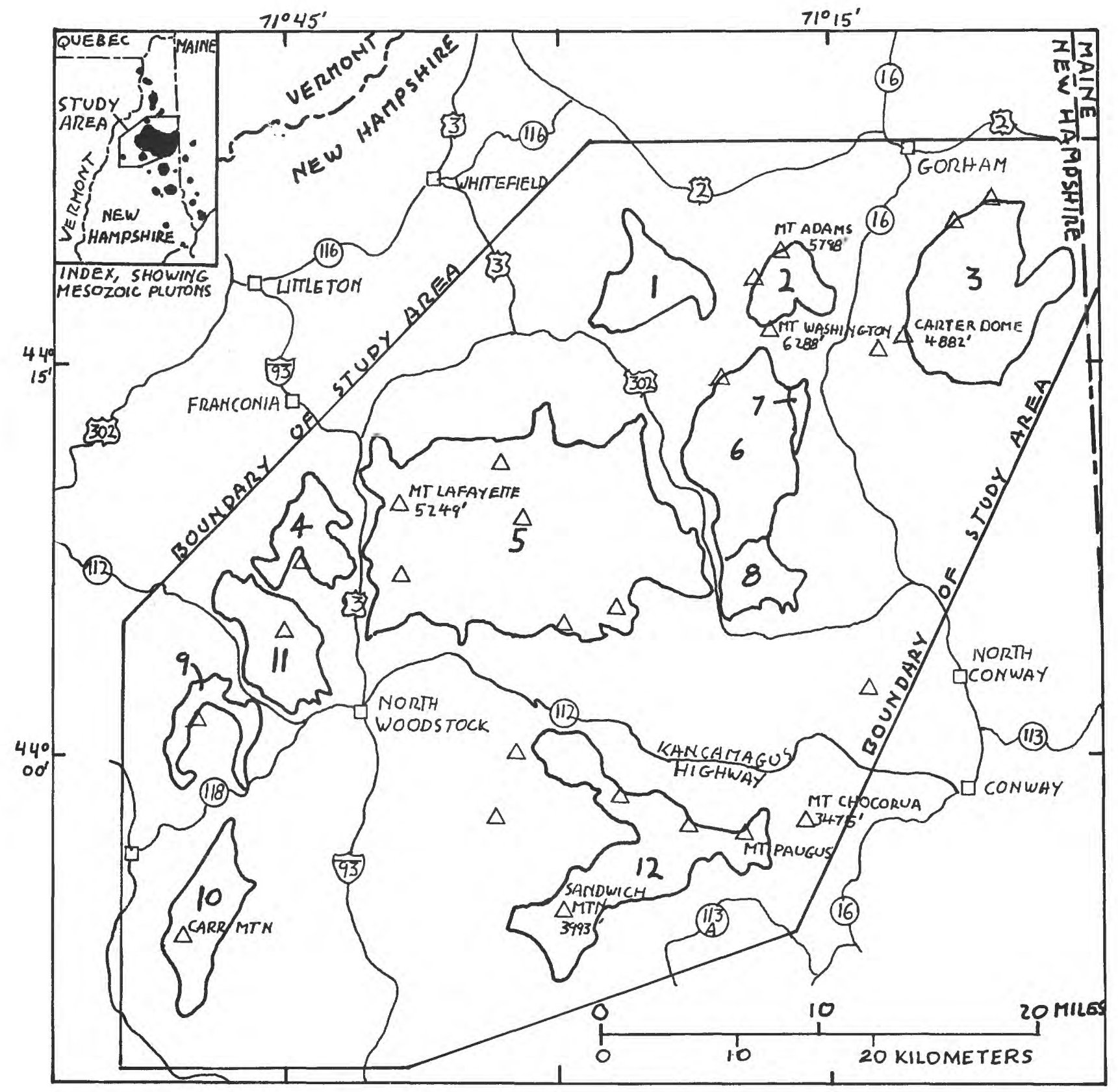

Figure 1.-Index map showing existing wilderness (EW), proposed wilderness (PW A), and further planning (FPA) areas of the White Mountain National Forest, New Hampshire: (1) Dartmouth Range FPA; (2) Great Gulf EW; (3) Wild River FPA; (4) Kinsman Mountain FPA; (5) Pemigewasset FPA; (6) Presidential Range-Dry River EW; (7, 8) Dry River Extension PWA; (9) Jobildunk FPA; (10) Carr Mountain FPA; (11) Mount Wolf-Gordon Pond FPA, and (12) Sandwich Range PWA. 


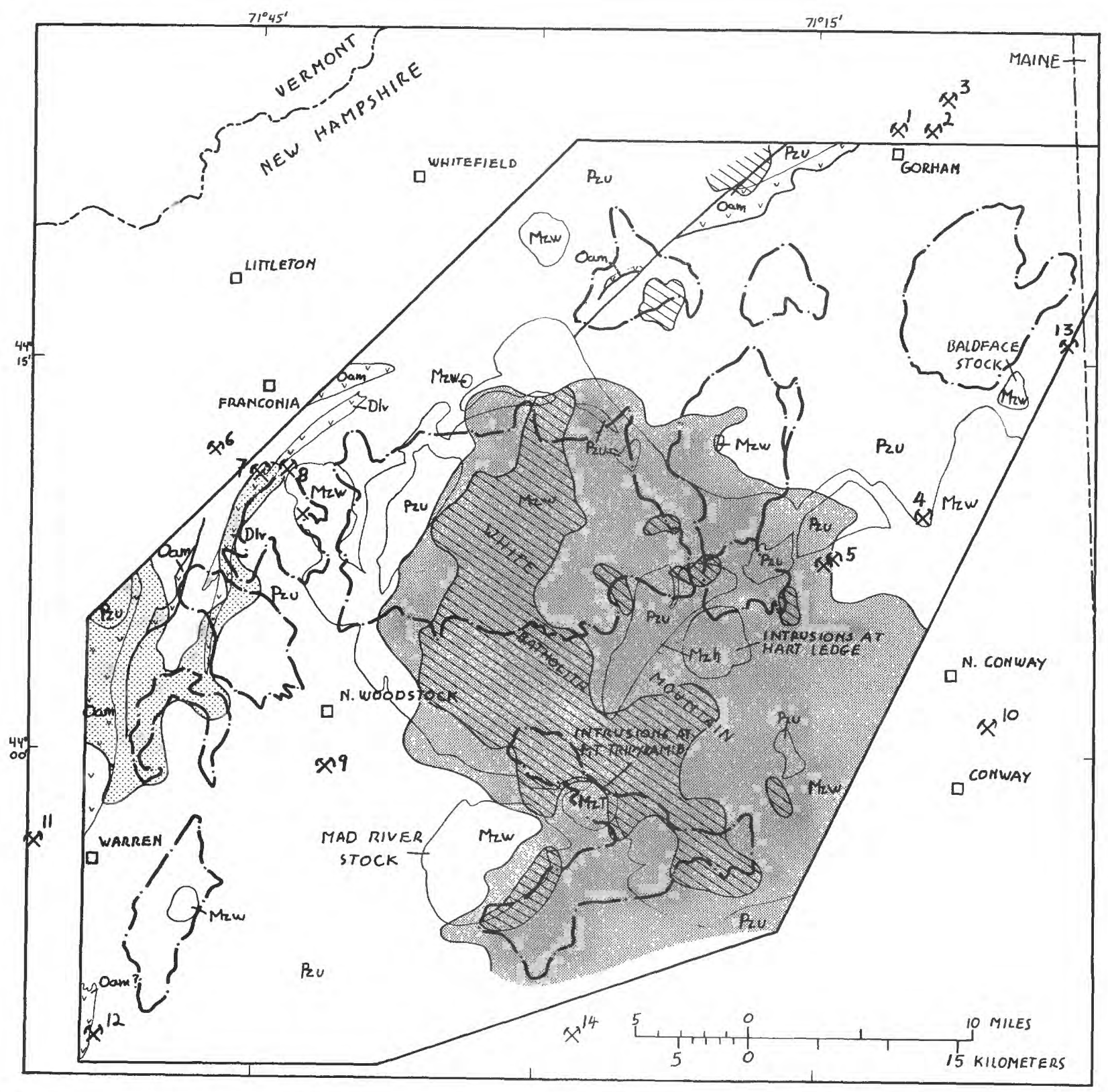

Figure 2.-Map showing mineral resource potential and geology of wilderness and roadless areas of the White Mountain National Forest, New Hampshire. Geology simplified from Hatch and Moench (in press). 


\section{EXPLANATION FOR FIGURE 2}

\section{WHITE MOUNTAIN PLUTONIC-VOLCANIC SUITE}

(CRETACEOUS TO TRIASSIC)

Mzt INTRUSIONS AT MOUNT TRIPYRAMID-Quartz syenite, monzonite, monzodiorite, and gabbro; isotopically dated quartz syenite is Cretaceous in age

Mzh INTRUSIONS AT HART LEDGE-Syenite, quartz syenite, and riebeckite granite; isotopically dated syenite is Cretaceous in age

Mzw WHITE MOUNTAIN BATHOLITH AND OUTLYING STOCKS-In order of decreasing abundance: Conway Granite; hornblende-, alkali amphibole-, and fayalite-bearing granite; quartz syenite and syenite; and gabbro (small bodies at Carr Mountain and in Dry River); isotopically dated rocks in study area are Jurassic in age

METAMORPHIC-PLUTONIC TERRANE

Pzu UNDIVIDED PLUTONIC AND HIGH-GRADE METAMORPHIC ROCKS (LOWER DEVONIAN TO ORDOVICIAN)

DIv LITTLETON FORMATION (LOWER DEVONIAN)-Metavolcanic rocks

Oam AMMONOOSUC VOLCANICS (ORDOVICIAN)-Metavolcanic rocks; possibly Silurian where queried

CONTACT

\section{FAULT}

MODERATE POTENTIAL FOR RESOURCES OF TIN AND ASSOCIATED LEAD, ZINC, URANIUM, NIOBIUM, BERYLLIUM, AND THORIUM

LOW POTENTIAL FOR RESOURCES OF TUNGSTEN (AND MOLYBDENUM), STRATABOUND COPPER, AND TIN IN VEINS

AREA OF URANIUM ANOMALY

APPROXIMATE BOUNDARY OF WILDERNESS OR ROADLESS AREA-Areas are named in figure 1

$\times \quad$ ABANDONED PROSPECT

x ABANDONED MINE-Number refers to description in text 
Hampshire rocks and structures that I sugges you have another look for tin in the Eastern States." 1 In fact, summary descriptions of the northern Nigerian tin district that can be read in several recent papers are almost interchangeable with one that might be written for the White Mountain Plutonic-Volcanic Suite (Bowden, 1982; Bowden and Kinnaird, 1978; Bowden and others, 1981; Olade, 1980; Imeokparia, 1982). The major difference is the age of the basement metamorphic-plutonic terrane, which is Precambrian in Nigeria and Paleozoic in New Hampshire. Sillitoe (1974) suggested that the Mesozoic plutonic-volcanic complexes of Nigeria and New Hampshire originated above mantle plumes or hot spots, but he was troubled by the apparent lack of tin mineralization associated with the White Mountain Suite. The anomalously high tin associated with the White Mountain batholith is amply demonstrated by the geochemical data.

Creasy (1974) made a regional geologic and petrologic study of the White Mountain batholith, and Hoisington (1977) studied the distribution of uranium and thorium in the rocks of the batholith, following several previous studies. Hoisington focused his work on the Conway Granite, which he divided into several petrographically and chemically distinctive plutons. Rocks of the Mesozoic White Mountain PlutonicVolcanic Suite are grouped on the basis of composition into six broad assemblages: (1) the Moat Volcanics, composed mainly of alkali rhyolite tuff, flows; and breccia, and minor trachyte; (2) gabbro; (3) syenite and quartz syenite; (4) various alkali-, amphibole-, fayalite-, and hornblende-bearing granites, including the Mount Osceola Granite and other named granites; (5) the Conway Granite (and small bodies of the Black Cap Granite); and (6) the relatively young intrusives at Mount Tripyramid and Hart Ledge.

Typically, the Conway Granite is medium- to coarse-grained, pink biotite granite containing pink perthite and white oligoclase. Locally, however, the Conway is greenish, apparently altered, and easily confused with the typically greenish, hornblendebearing Mount Osceola Granite. The Conway typically contains accessory fluorite, and locally contains accessory topaz, beryllium minerals, thorite, and molybdenite (Hoisington, 1977); cassiterite has not been reported. Liese (1973) detected 0.01-0.02 percent tin in several biotite separates from the Conway Granite. These values are intermediate between those obtained by Imeokparia (1982) in tinbearing and tin-barren Jurassic Nigerian granites. Accessory ilmenite is ubiquitous in the Conway, but magnetite also is present locally, suggesting that the Conway is not strictly an ilmenite-series granite (Ishihara, 1982) of the type characteristic of CircumPacific tin districts.

The Conway Granite is well known for its high radioactivity and high uranium and thorium contents. It has been considered as a possible low-grade source of uranium and thorium, as the source of uranium that might be found in secondary deposits, and as a geothermal energy resource (Bothner, 1978; Page, 1980; Osberg and others, 1978). Page (1980) cited estimated average contents of $11 \mathrm{ppm}$ uranium and 53 ppm thorium in the Conway Granite. According to Hoisington (1977), average uranium contents range from 10 to $13 \mathrm{ppm}$ and average thorium contents range from 45 to $80 \mathrm{ppm}$ from one pluton of the Conway to another. The data listed in table 1 demonstrate that the Conway is metal-specialized according to the criteria of Tischendorf (1977). Except for higher $\mathrm{K}_{2} \mathrm{O}: \mathrm{Na}_{2} \mathrm{O}$ ratios and slightly higher $\mathrm{FeO}$ and $\mathrm{CaO}$ contents in the Conway, average Conway Granite is remarkably similar to average Jurassic biotite granite of northern Nigeria in major-oxide and minor-element composition (table 1). As shown by Tischendorf (1977), specialized granites tend to have high silica and potassium contents, and they are characterized by exceptionally low titanium, iron, magnesium, and calcium contents. Average Jurassic Nigerian biotite granite contains about $50 \mathrm{ppm}$ thorium (Olade, 1980, table 1), in accord with the Conway Granite. Tin contents of the stanniferous and mineralized granites specifically studied by Olade (1980, table 2) have arithmetic averages of $22 \mathrm{ppm}$ tin, and ranges of 2-114 ppm tin (stansiferous) and 2-1.17 ppm tin (mineralized). The average tin content of $13 \mathrm{ppm}$ tin in six samples (table 1) of Conway Granite is low, but it represents almost the only reliable data on tin in the Conway; the six samples range from 0 to $45 \mathrm{ppm}$ tin. Interestingly, the highest tin contents in the Conway occur in two samples having the highest rubidium contents and low $\mathrm{K}: \mathrm{Rb}$ ratios (17 ppm $\mathrm{Sn}, 478 \mathrm{ppm} \mathrm{Rb}$, $\mathrm{K}: \mathrm{Rb}$ 96:1; 45 ppm Sn, 636 ppm Rb, K:Rb 58:1). Both samples were collected from outcrops that lie just outside the area of the principal anomaly. Hoisington (1977) observed that different bodies of the Conway have different petrographic and chemical characteristics. Rocks of the small Baldface stock, in the northeastern part of the area, have the highest rubidium contents and the lowest $\mathrm{K}: \mathrm{Rb}$ ratios labout 40-60: 1; Hoisington, 1977, fig. 8), suggesting that this body has the highest degree of specialization. Although it would be premature to judge the potential of a pluton on the basis of the present knowledge of petrochemical details, Hoisington's approach should be investigated.

The geochemical data resulting from the regional geochemical survey (Canney and others, in press) and the investigation in the Pemigewassett Roadless Area (Sabin and others, 1982) have delineated a major tin anomaly, shown in figure 2 as area $\mathrm{A}$, covering about $300 \mathrm{mi}^{2}$ in north-central New Hampshire, and centering on the White Mountain batholith. The principal anomaly is defined on the basis of exceptionally abundant tin in heavy-mineral concentrates, and it incorporates smaller but welldefined areas of anomalous tin, uranium, zinc, lead, niobium, and beryllium in stream-sediment samples, and thorium and niobium in heavy-mineral concentrates of stream sediments. Sharply angular grains of cassiterite as much as 0.1 in. across were identified in some of the concentrates; not all of the tin, however, is necessarily in the form of cassiterite. Topaz, characteristic of tin greisens, also was identified. Because this major tin anomaly overlaps the margin of the batholith and extends far outside areas underlain by the Conway Granite, the presumed source of the tin, the anomaly probably is not solely the result of residual concentration of accessory cassiterite in the Conway. Almost certainly the tin of

${ }^{1}$ We are indebted to Peter W. Lipman for calling attention to this quote. 
Table 1.--Chemisıry of Conway and Mount Osceola Granites (Triassic to Cretaceous) of the White Mountain batholith and nearby two-mica granite (Devonian) compared with normal and specialized granites (Tischendorf, 1977) and Jurassic biotite granite in northern Nigeria (01ade, 1980)

[Leaders (--) indicate no data; >, greater than; <, less than. Samples for data shown in columns 4,6 , and 8 analyzed by laboratorles of U.S. Geological Survey, Denver, Colo.: major oxides analyzed by J. S. Wah1berg, A. J. Barte1, J. E. Taggert, Jr., and J. W. Baker; fluorine analyzed by D. B. Hatfield; rubidium, strontium, and tin analyzed by Patty Billings]

\begin{tabular}{|c|c|c|c|c|c|c|c|c|}
\hline $\begin{array}{l}\text { Sample type- } \\
\text { Oxide/Element }\end{array}$ & $\begin{array}{c}- \text { Normal } \\
\quad\left(\begin{array}{l}1 \\
t\end{array}\right. \\
\end{array}$ & $\begin{array}{c}\text { Special } \\
\left({ }^{2}\right)\end{array}$ & $\begin{array}{c}\text { Nigerian } \\
\left({ }^{3}\right)\end{array}$ & $\left({ }^{4}\right)^{\mathrm{Co}}$ & (5) & $\begin{array}{l}\text { Mount } \\
\left({ }^{6}\right)\end{array}$ & $\begin{array}{r}\text { Osceola } \\
\left({ }^{7}\right)\end{array}$ & $\begin{array}{c}\text { Two-mica } \\
\left({ }^{8}\right)\end{array}$ \\
\hline \multicolumn{9}{|c|}{ Major oxides, in percent } \\
\hline $\mathrm{SiO}_{2}$ & 70.84 & 73.38 & 75.49 & 74.40 & 73.14 & 67.30 & 71.70 & 71.45 \\
\hline $\mathrm{Al}_{2} \mathrm{O}_{3}$ & 14.33 & 13.97 & 12.62 & 13.60 & 13.34 & 15.30 & 13.33 & 15.30 \\
\hline${ }^{9} \mathrm{FeO}$ & 2.49 & 1.92 & 1.58 & 1.84 & 2.82 & 3.42 & 2.63 & 1.59 \\
\hline MgO & .81 & .47 & .16 & $<.16$ & .15 & $<.10$ & .15 & .43 \\
\hline $\mathrm{CaO}$ & 1.89 & .75 & .54 & .69 & .74 & .95 & .99 & 1.15 \\
\hline $\mathrm{Na}_{2} \mathrm{O}$ & 3.44 & 3.20 & 4.18 & 3.61 & 3.56 & 4.70 & 4.07 & 3.44 \\
\hline $\mathrm{K}_{2} \mathrm{O}$ & 4.34 & 4.69 & 4.63 & 5.27 & 5.38 & 5.90 & 5.17 & 4.58 \\
\hline $\mathrm{TiO}_{2}$ & .34 & .16 & .12 & .16 & .18 & .27 & .29 & .23 \\
\hline $\mathrm{P}_{2} \mathrm{O}_{5}$ & $\rightarrow$ & - & .03 & $<.06$ & .06 & $<.05$ & .10 & .19 \\
\hline Mno & .06 & .05 & .02 & $<.03$ & .05 & .14 & .09 & .04 \\
\hline $\mathbf{F}$ & .09 & .37 & .43 & .27 & - & .12 & - & .14 \\
\hline \multicolumn{9}{|c|}{ Minor elements, in parts per million, and $\mathrm{K}: \mathrm{Rb}$ ratio } \\
\hline Li & 40 & 400 & 80 & 78 & -- & 8 & - & 92 \\
\hline $\mathrm{Rb}$ & 200 & 580 & 405 & 438 & -- & 350 & -- & 256 \\
\hline Sr & - & -- & $<100$ & 49 & -- & 13 & - & 191 \\
\hline $\mathrm{Sn}$ & 3 & 40 & $<30$ & 13 & -- & 8 & -- & $<3$ \\
\hline $\mathrm{K}: \mathrm{Rb}$ & $>100$ & $<100$ & 95 & 104 & - & 140 & - & 149 \\
\hline
\end{tabular}

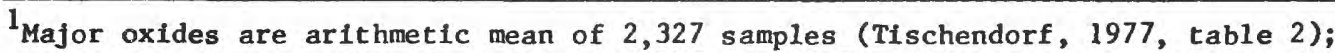

minor elements from Tischendorf (1977, p. $56-71,87)$.
${ }^{2}$ Major oxides are arithmetic mean of 962 samples (Tischendorf, 1977, table 2); minor elements from Tischendrof (1977, p. 56-71, 87).

${ }^{3}$ Average composition of Maine younger granite (Jurassic) biotite granite from olade (1980, table 1).

${ }^{4}$ Arithmetic mean of six samples of Conway Granite from White Mountain batholith and Wild River stock; range from tin content is $0-45 \mathrm{ppm}$.

${ }^{5}$ Arithmetic mean of five samples of Conway Granite from White Mountain batholith (Butler, 1975, table 3).

6 One sample of Mount Osceola Granite from White Mountain batholith.

${ }^{7}$ Arithmetic mean of six samples of Mount Osceola Granite from White Mountain batholith (Butler, 1975, table 3).

${ }^{8}$ Arithmetic mean of six samples of two-mica granite (Devonian) intruded by White Mountain batholith.

${ }^{9} \mathrm{FeO}=\mathrm{FeO}+.9 \mathrm{Fe}_{2} \mathrm{O}_{3}$. 
the anomaly is derived from deposits now present in bedrock, for several heavy-mineral concentrates having 2,000 ppm or more tin were obtained from rapid mountain streams, some at high altitudes, where residual placer concentrates from eroded deposits would have been carried away long ago. This interpretation is strengthened by the fact that the anomaly is also defined by abundant tin detected in fine-grained bulk samples of stream sediments as well as in heavy-mineral concentrates.

By analogy with the Nigerian setting (Olade, 1980), bedrock tin deposits in the study area could occur (1) as low-grade disseminations of cassiterite in the margins and roof zones of the biotite granites (Conway Granite) formed at subsolidus temperatures shortly after solidification of the granite; and (2) as younger fracture-controlled lodes and greisen veins containing cassiterite, several sulfide minerals, and wolframite. Other types of bedrock and placer mineral deposits may also occur in the study area.

In Nigeria, fracture-controlled cassiterite is found mainly in the greisens, and sphalerite is in massive and vuggy quartz (Olade, 1980, p. 73). In New Hampshire, vein-type tin mineralization is represented at the long-abandoned Jackson tin mine (fig. 2, no. 4), The lead-zinc veins or disseminations at the Mascot, Stevens, Shelburne, Brock and Company, and North Woodstock mines or prospects (fig. 2, nos. 1, 2, 3, 8, and 9) are part of a belt of 11 known similar fracturedcontrolled, commonly argentiferous lead-zinc deposits in New Hampshire. The known deposits of this type are outside the area of the principal tin anomaly. The belt of deposits, however, broadly coincides with the belt of plutons and igneous complexes of the White Mountain Suite. Cox (1970) inferred a genetic relationship.

The magnetite-phenacite deposit at Iron Mountain (fig. 2, no. 5) is interpreted as a replacement skarn in Conway Granite. The deposit has a low tin content, but contains high-grade concentrations of beryllium, zinc, lead, and silver. Barton and Goldsmith (1968), who described the deposit in detail, suggested that the Conway Granite and its contacts should be explored for other deposits of this type. Some of the small positive aeromagnetic anomalies (Bothner, in press) might reflect such bodies. Ground magnetic surveys might help to delineate the deposits further. All these deposits occur outside the area of the principal anomaly, and all except the Iron Mountain replacement deposit occur in rocks of the Paleozoic metamorphic-plutonic terrane. Although all are insignificant as individual deposits, their variety and their distribution relative to the principal tin anomaly suggest that they are peripheral to the area of more intense mineralization within the anomaly.

The tin anomaly covers a very large area and probably represents many, far smaller centers of mineralization. Further studies are needed to delineate some of these centers, particularly cupolas, if any have survived erosion, and to delineate mineralized contact zones of plutons of the Conway Granite. Because the principal anomaly extends beyond the margins of the White Mountain batholith, it could be argued that the scattered lead-zinc-silver veins and the one locality of tin veins farther outside the batholith are related to mineralization above or around plutons that have not yet been exposed by erosion.
As in known tin districts, fracture-controlled mineralization may be important. Possible regional fracture systems in the study area can be seen on a preliminary lineament map prepared by Howard A. Pohn and Donald Segal (written commun., 1.982) from satellite photographs. The most conspicuous feature is a belt of lineaments about 6-8 mi wide that trends $\mathrm{N}$. $25^{\circ}-30^{\circ} \mathrm{W}$. across the batholith, subparallel to the long dimension of the tin anomaly defined by the sediment samples. Also visible is a concentric pattern around the Baldface stock of the Conway Granite. Further studies should include field investigations of fracture patterns.

Fehn and others (1978) have suggested that veintype uranium deposits may form by hydrothermal convection long after crystallization of exceptionally uraniferous plutons, such as the Conway plutons. Such a process might account for the uranium anomaly that coincides with the tin anomaly. The possibility should be considered that hydrothermal convection induced by radiogenic heating long after emplacement of the batholith might result in tin as well as uranium veins.

\section{MINING AND MINERALIZATION}

The study area has no active mines and only minor past mineral production. The largest mine within or near the study area, at Ore Hill, near Warren (fig. 2, no. 11), yielded about 100,000 tons of zinc-lead massive-sulfide ore, mainly prior to 1905 . The only known mining or prospecting within the boundary of a roadless area occurred before 1900 in the Kinsman Mountain area; a small lead mine (fig. 2, no. 8) and a silver prospect there are mentioned in the literature but were not located during fieldwork. The collecting and sale of gemstones and mineral specimens is locally important. There is no other current production of nonmetallic minerals, such as dimension stone, refractory minerals (sillimanite), industrial pegmatite minerals (feldspar and mica), peat, and diatomaceous earth. Sand and gravel are currently produced from a number of pits in the area.

Of the 217,971 acres that constitute the wilderness and roadless areas in the White Mountain National Forest, the Federal Government owns 99.6 percent of the surface area and 98.7 percent of the mineral rights.

No outstanding prospecting or mining permits are known within the boundaries of the White Mountain National Forest, but several applications have been filed for prospecting permits. Applications were filed in 1977 for uranium- and thorium-prospecting permits; they are for areas south of the Pemigewasset area along the Kancamagus Highway. Applications for permits were filed in 1978 to prospect for base and precious metals near the western boundary of the forest. In 1982, several applications to prospect for tin, tungsten, and associated base metals were filed for the area south of the Pemigewassett area and included tracts within the boundaries of the Sandwich Range Roadless Area. Permit application boundaries also extend into small parts of the Pemigewassett, and Jobildunk areas. As of June 1983, none of the applications had been approved.

Descriptions of 14 abandoned mines, prospects, and quarries follow; their numbers are keyed to figure 2 .

1. Mascot mine-about 1 mi north of Gorham, north 
of study area. Vein that strikes N. $35^{\circ} \mathrm{E}$, and dips $70^{\circ} \mathrm{NW}$. in granite. Breccia filled with quartz, argentiferous galena, sphalerite, and sparse chalcopyrite (Billings and FowlerBillings, 1975; Cox, 1970).

2. Stevens prospect-about $2 \mathrm{mi}$ northeast of Gorham, north of study area. Vein probably similar in attitude and composition to vein at Mascot mine (Billings and Fowler-Billings, 1975).

3. Shelburne mine-about $4 \mathrm{mi}$ northeast of Gorham, north of study area. Silicified and mineralized shear zone about 10-15 ft wide, strikes N. $75^{\circ}$ E. and dips $65^{\circ}$ N.; silver-bearing galena, sphalerite, sparse chalcopyrite, quartz, arsenopyrite, and manganiferous siderite in silicified country rock (Billings and FowlerBillings, 1975; Cox, 1970).

4. Jackson tin mine-about 1 mi east of Jackson, near east-central margin of study area. Thin, sharply defined veins in schist; the veins are composed of massive cassiterite and small amounts of arsenopyrite, chalcopyrite, wolframite, fluorite, and molybdenite. Selected high-grade ore in veins as much as $8 \mathrm{in}$. thick yielded as much as 30 percent tin (Hitchcock, 1878; Jackson, 1844).

5. Iron Mountain mine-on south slope of Iron Mountain, about $4 \mathrm{mi}$ northeast of Bartlett, in east-central part of study area. Veins and replacements of magnetite and phenacite $\left(\mathrm{BeSiO}_{4}\right)$ in Conway Granite; investigated by Barton and Goldsmith (1968) as a possible source of beryllium. The fluorite, phenacite, and danalite-helvite $\left((\mathrm{FeMn})_{4}\left(\mathrm{Be}_{3} \mathrm{Si}_{3}\right) 12 \mathrm{~S}\right)$; common drusy quartz and small veinlets of galena, sphalerite, and pyrite.

6. Franconia iron mine-on Ore Hill, about $3 \mathrm{mi}$ southwest of Franconia, northwest of study area. A narrow layer of banded quartzmagnetite iron-formation that lies between pyritic felsic schist and basaltic amphibolite, and grades northward along strike to laminated magnetite-biotite felsic schist. Local thin lenses of garnet and epidosite. Interpreted as metamorphosed, volcanic, exhalative, ironformation (Annis, 1982).

7. Coppermine Brook mine-Small overgrown trenches and a water-filled pit on the banks of Coppermine Brook, and possible underground workings extending to a depth of $200 \mathrm{ft}$ (Hammack and Girol, 1972). Where exposed at the entrance to one trench on the north side of the brook, the ore-bearing zone is about 6 in. thick and is composed of fine-grained siliceous mica schist containing disseminated chalcopyrite. The zone lies above dark, finegrained, locally amygdalloidal and porphyritic amphibolite, and below poorly to conspicuously layered light-colored biotite-quartz-feldspar gneiss containing 2 X $3 \mathrm{~mm}$ quartz "eyes." A syngenetic origin is consistent with the habit of the deposit. The deposit may have accumulated in small depressions on the sea floor during the change from basaltic to silicic volcanism.

8. Brook and Company mine-location uncertain, a short distance north of Coppermine Brook, near northwest margin of study area; probably a galena-bearing vein. Developed by small open pit (Hammack and Girol, 1982).

9. North Woodstock mine-about $3 \mathrm{mi}$ south of North Woodstock, in southwest-central part of study area. Silver-bearing galena, and sparse sphalerite and pyrite disseminated in schist and granite altered to quartz, sericite, and ankerite. Ore is adjacent to a minor fault that strikes N. $28^{\circ} \mathrm{W}$. and dips $78^{\circ} \mathrm{E}$. and is widest where it crosses granite (Cox, 1970).

10. Redstone Quarry-about $3 \mathrm{mi}$ south of North Conway, southeast of study area. Abandoned major building stone quarry in Conway Granite.

11. Ore Hill (Warren) mine-about $3 \mathrm{mi}$ northwest of Warren, N.H., west of study area; occurs in an area underlain by the Ammonosuc Volcanics. Stratabound lenses of zinc-lead-copper ore in a host of phlogopitic quartz-muscovite schist and other premetamorphically altered metavolcanic rocks; the host lies above epidotic amphibolite interpreted as metabasalt, and below stratified light-colored garnetiferous biotite-quartzfeldspar gneiss interpreted as felsic metatuff. The mine yielded about 100,000 tons of ore, mainly prior to 1905 , but was also worked during World War I (Secord and Brown, 1983; Gair and Slack, 1979).

12. Atwood pegmatite mine-southwest of Carr Mountain, at southwest corner of study area. Mica, mainly sheet muscovite about 4 by 5 in., some as large as 18 by 18 in. (Cameron and others, 1954).

13. Millard Chandler pegmatite mine-northeast of Baldface Mountain, just east of study area. Minor production of feldspar and beryl. The beryl occurs as crystals as large as 6 by 15 in. in the intermediate zone of the pegmatite where it constitutes about 0.1 percent of the rock; no sheet mica seen (see Gazdik and others, in press).

14. White Diamond mine-about $2 \mathrm{mi}$ northwest of Sandwich Center, south of study area. Minor production of gold from a large silicified zone (see Gazdik and others, in press).

\section{ASSESSMENT OF MINERAL RESOURCE POTENTIAL}

A moderate resource potential for tin deposits and for associated deposits containing lead, zinc, uranium, niobium, beryllium, and thorium is assigned to an area of about $300 \mathrm{mi}^{2}$ (area A) that overlaps the following areas of the White Mountain National Forest in New Hampshire: approximately the eastern twothirds of the Pemigewasset Roadless Area, all of the Sandwich Range Roadless Area, the southern half of the Presidential Range-Dry River Wilderness Area, and the southern parcel of the Dry River Extension Roadless Area.

These tin deposits, possibly of several types related to the Conway Granite, occur both within and outside areas underlain by the Conway. The classification is based on $2,000 \mathrm{ppm}$ or more tin in most heavy-mineral concentrates of stream sediments obtained from area $\mathrm{A}$, and 20 to $700 \mathrm{ppm}$ tin in 86 percent of the stream-sediment samples that were collected from a slightly smaller area within area $\mathrm{A}$. The classification is supported by well-defined geochemical anomalies of uranium, lead, zinc, 
beryllium, niobium, and thorium within area $\mathrm{A}$, and by evidence that the Conway Granite is tin-specialized. This classification is further supported by the similarity of the White Mountain Plutonic-Volcanic suite and the Jurassic igneous complexes of the Nigerian tin districts (Read, 1948). With the exception of the deposits at the few small mines and prospects in the study area, however, evidence for important mineralization has not yet been found in bedrock.

The deposits in area A possibly include placer accumulations of cassiterite in gravels along the major drainages. Bedrock tin deposits could occur as (1) lowgrade disseminations along contacts and roof zones (if they still exist) of the Conway Granite; (2) as higher grade fracture-controlled lodes and greisens in roof zones of Conway plutons (again, if the cupolas have not been eroded); or (3) as high-grade veins, containing cassiterite, several sulfide minerals, and wolframite, in Paleozoic schist or granite, as at the Jackson tin mine.

Large parts of area $A$ also have moderate resource potential for uranium in veins, or secondary accumulations of uranium in fracture zones in the Conway Granite; for possibly argentiferous lead-zinc veins, as at several small abandoned mines outside area $A$; and for replacement magnetite-phenacite $\left(\mathrm{BeSiO}_{4}\right)$ skarns having low contents of tin, but highgrade concentrations of beryllium, zinc, lead, and silver, as at the Iron Mountain mine. Deposits of unknown type may also contain large amounts of thorium and niobium, in addition to the other metals that define the geochemical anomalies of area A. Deposits of tin and other metals may have formed at high temperatures immediately after emplacement of the Conway plutons, or at lower temperatures possibly long after emplacement, by precipitation from radioactively heated circulating ground water, as suggested by Fehn and others (1978) for postulated uranium-bearing veins.

A low mineral resource potential for deposits of several types containing tungsten, molybdenum, copper, and tin is assigned to a much smaller, and geologically less favorable north-northeast-trending area of about $35 \mathrm{mi}^{2}$ (area B) that covers most of the Jobildunk and small parts of the Mount Wolf-Gordon Pond and Kinsman Mountain Roadless Areas. These deposits are of the following types: (1) stratabound deposits of tungsten (and molybdenum) in metavolcanic rocks and metagraywacke of the Littleton Formation and in the Ammonoosuc Volcanics; (2) stratabound volcanogenic copper deposits in metavolcanic rocks of the Littleton Formation, as at the Coppermine Brook mine; and (3) volcanogenic copper-lead-zinc massivesulfide deposits in the Ammonoosuc Volcanics, as at the Ore Hill mine. Tin-bearing veins may occur in a narrow belt that extends northwest from the tin anomaly adjacent to area B across the summit of Mount Moosilauke. The classification is defined on the basis of analyses of heavy-mineral concentrates from stream sediments that yielded as much as 3,000 ppm tungsten, $500 \mathrm{ppm}$ molybdenum, 3,000 ppm copper (maximum obtained downstream from Coppermine Brook mine), and more than 2,000 ppm tin, and on the known sulfide mineral deposits in and near the area. The suggested occurrence of stratabound tungsten deposits, of recent interest elsewhere in the world, is highly speculative and needs further investigation in New England.
Nonmetallic commodities such as sand and gravel, dimension stone, refractory minerals, industrial pegmatite minerals, gems, peat, and diatomaceous earth occur in the study area, but larger, much better and more accessible deposits occur elsewhere in the region. For discussion of these commodities, readers are referred to Gazdik and others (in press).

\section{REFERENCES}

Annis, M. P., 1982, Banded magnetite-quartz ironformation in the Ammonoosuc volcanics, Sugar Hill, New Hampshire: Geological Society of America Abstracts with Programs, v. 14, nos. 12, p. 2.

Barton, W. P., and Goldsmith, C. E., 1968, New England beryllium investigations: U.S. Bureau of Mines Report of Investigations 7070, p. 51122.

Billings, M. Po, 1937, Regional metamorphism of the Littleton-Moosilauke area, New Hampshire: Geological Society of America Bulletin, v. 48, p. 463-566.

Billings, M. P., and Fowler-Billings, Katherine, 1975, Geology of the Gorham quadrangle, New Hampshire: New Hampshire Department of Resources and Economic Development Bulletin $6,120 \mathrm{p}$.

Bothner, W. A., 1978, Selected uranium and uraniumthorium occurrences in New Hampshire: U.S. Geological Survey Open-File Report 78-482, 42 p.

in press, Gravity and magnetic maps of the wilderness and roadless areas of the White Mountain National Forest, New Hampshire: U.S. Geological Survey Miscellaneous Field Studies Map MF-1594-D, scale 1:125,000.

Boudette, E. L., 1977, Two-mica granite and uranium potential in the northern Appalachian orogen of New England: U.S. Geological Survey Circular 753 , p. 23-24.

Bowden, P., 1982, Magmatic evolution and mineralization in the Nigerian Younger Granite Province, in Evan, A. M., ed., Metallization associated with acid magmatism: John Wiley \& Sons, v. 6, p. 51-61.

Bowden, P., and Kinnaird, J. A., 1978, Younger granites of Nigeria-a zinc-rich tin province: Institute of Mining and Metallurgy Transactions, v. 87, p. B66-B69.

Bowden, P., Bennett, J. N., Kinnaird, J. A., Whitley, J. E., and Abaa, S. I., 1981, Uranium in the NigerNigeria Younger Granite Province: Mineralogical Magazine, v. 44, p. 379-389.

Cameron, E. N., Larrabee, D. M., McNair, A. H., Page, J. J., Stewart, G. W., and Shainin, V. E., 1954, Pegmatite investigations, 1942-45, New England: U.S. Geological Survey Professional Paper 255, 352 p.

Canney, F. C., Howd, F. H., Domenico, J. A., and Nakagawa, H. M., in press, Geochemical survey of the wilderness and roadless areas of the White Mountain National Forest, New Hampshire: U.S. Geological Survey Miscellaneous Field Studies Map MF-1594-C, scale $1: 125,000$. 
Cox, D. P., 1970, Lead-rinc-silver deposits related to the White Mountain Plutonic Series in New Hampshire and Maine: U.S. Geological Survey Bulletin 1312-D, p. D1-D18.

Creasy, J. W., 1974, Mineralogy and petrology of the White Mountain batholith, Franconia, and Crawford Notch quadrangles, New Hampshire: Cambridge, Mass., Harvard University $\mathrm{Ph} . \mathrm{D}$. thesis, $430 \mathrm{p}$.

Eby, G. N., and Creasy, J. W., 1983, Strontium and lead isotope geology of the Jurassic White Mountain batholith, New Hampshire: Geological Society of America Abstracts with Programs, v. 15, no. 3, p. 188.

Fehn, U., Cathles, L. M., and Holland, H. D., 1978, Hydrothermal convection and uranium deposits in abnormally radioactive plutons: Economic Geology, v. 73, p. 1556-1566.

Gair, J. E., and Slack, J. F., 1979, Map showing lithostratigraphic and structural setting of stratabound (massive) sulfide deposits of the U.S. Appalachians, with available chemical and reserve data on the deposits: U.S. Geological Survey Open-File Report 79-1517, scale $1: 1,000,000$.

Gazdik, G. C., Harris, L. E., Welsh, R. A., and Girol, V. P., in press, Mines, prospects, and mineral sites of the wilderness and roadless areas of the White Mountain National Forest, New Hampshire: U.S. Geological Survey Miscellaneous Field Studies Map MF-1594-E, scale 1:125,000.

Hammack, R. W., and Girol, V. P., 1982, Mineral resources of Kinsman Mountain RARE II Further Planning Area, Grafton County, New Hampshire: U.S. Bureau of Mines Open-File Report 58-82, 15 p.

Hatch, N. L., Jro, and Moench, R. H., in press, Geologic map of the wilderness and roadless areas of the White Mountain National Forest, New Hampshire: U.S. Geological Survey Miscellaneous Field Studies Map MF-1594-A, scale 1:125,000.

Hitchcock, C. E., 1878, Economic geology, Pt. 5, of The geology of New Hampshire: Concord, $\overline{\mathrm{N}}$. H., State of New Hampshire, 66 p.

Hoisington, D. W., 1977, Uranium and thorium distribution in the Conway Granite of the White Mountain batholith: Hanover, N. H., Dartmouth College M.A. thesis, 108 p.
Imeokparia, E. G., 1982, Tin content of biotites from the Afu Younger Granite Complex, central Nigeria: Economic Geology, v. 77, p. 17101724.

Ishihara, Shunso, 1981, The granitoid series and mineralization, in Skinner, B. J., ed., Economic Geology 75th Anniversary Volume: Lancaster, Pa., Economic Geology Publishing Company, p. 458-484.

Jackson, C. T., 1844, Final report on the geology and mineralogy of the State of New Hampshire: Concord, State of New Hampshire, 376 p.

Liese, H. C., 1973, Mineral composition of the Conway Granite in New Hampshire: Geological Society of America Bulletin, v. 84, p. 331-334.

Olade, M. A., 1980, Geochemical characteristics of tin-bearing and tin-barren granites, northern Nigeria: Economic Geology, v. 75, p. 71-82.

Osberg, P. H., Wetteraurer, Richard, Rivers, Mark, Bothner, W. A., and Creasy, J. W., 1978, Feasibility study of the Conway Granie as a geothermal entrgy resource: Available from U.S. National Technical Information Service C00-2686-1, $184 \mathrm{p}$.

Page, L. R., 1980, Guides for prospecting for uranium and thorium in New Hampshire and adjacent areas: U.S. Geological Survey Open-File Report 80-657, 23 p.

Read, H. H., 1948, Granites and granites: Geological Society of America Memoir 28, p. 1-19.

Sabin, A. E., Clay, M. M., and Thompson, R. M., 1982, Mineral investigation of Pemigewassett RARE II Further Planning Area, Grafton and Carroll Counties, New Hampshire: U.S. Bureau of Mines Open-File Report MLA 95-82, 16 p.

Secord, T. K., and Brown, P. E., 1983, Geology and geochemistry of the Ore Hill $\mathrm{Zn}-\mathrm{Pb}-\mathrm{Cu}$ deposit, Warren, New Hampshire: Geological Society of America Abstracts with Programs, v. 15, no. 6, p. 682.

Sillitoe, R. H., 1974, Tin mineralization above mantle hot spots: Nature, v. 248, p. 497-499.

Tischendorf, G., 1977, Geochemical and petrographic characteristics of silicic magmatic rocks associated with rare-element mineralization, in Stemprok, M., and others, eds., Metallization associated with acid magmatism: Prague, Czechoslovakia Geological Survey, v. 2, p. 4196. 